\title{
A Simple Method for Isolation of Polymannuronate and Polyguluronate from Alginate Hydrolyzed by Organic Acids
}

\author{
Dong Soo Lee, Myung Kyo Shin ${ }^{1}$, Jae Hyeung Pyeun ${ }^{2}$ and Jin Woo Lee ${ }^{3} *$ \\ Research Center of Biotechnology \& Bioengineering, KBP Co., Ltd, Pyungtaek, Kyunggi 459-050, Korea \\ ${ }^{1}$ Division of Environment and Energy, Korean Institute of Industrial Technology, Cheonansi, Chungnam 330-825, Korea \\ ${ }^{2}$ Faculty of Food Science and Biotechnology, Pukyong National University, Busan, 608-737, Korea \\ ${ }^{3}$ Department of Biotechnology, Dong-A University, Busan 604-714, Korea
}

Received October 24, 2008 /Accepted January 9, 2009

\begin{abstract}
Alginate with a MW of $1,283 \mathrm{kDa}$ was hydrolyzed with $0.4 \mathrm{M}$ organic acids at $100^{\circ} \mathrm{C}$ for $3 \mathrm{hr}$. Molecular weights of alginates hydrolyzed with organic acids ranged from 7.5 to $53.2 \mathrm{kDa}$. There was no significant difference in the molar ratio of mannuronate to guluronate in alginates hydrolyzed with organic acids. Acetic acid was found to be the most effective organic acid for hydrolysis of alginate. The MW of alginate decreased with increasing concentration and reaction time with acetic acid as a hydrolyzing agent. The correlations between the MW of hydrolyzed alginate and concentration of acetic acid as well as reaction time with $0.4 \mathrm{M}$ acetic acid were plotted and the relevant equations obtained in this study. Polymannuronate and polyguluronate were isolated by $\mathrm{pH}$ adjustment of alginate hydrolyzed with $0.4 \mathrm{M}$ acetic acid. The molar percentages of mannuronate in polymannuronates isolated from alginate hydrolyzed with $0.4 \mathrm{M}$ acetic acid at $100^{\circ} \mathrm{C}$ were increasing in proportional to the reaction time such as $75 \%$ for $1 \mathrm{hr}, 90 \%$ for $3 \mathrm{hr}$, and $98 \%$ for $5 \mathrm{hr}$ of reaction time.
\end{abstract}

Key words : Alginate, hydrolysis, polymannuronate, polyguluronate, organic acids

\section{Introduction}

Seaweed alginates consist of $\beta$-D-mannuronate and its C-5 epimer, $\alpha$-L-guluronate $[5,14,20]$. Alginates are widely used industrially as stabilizers, emulsifiers and gelling agents because of their ability to retain water. The molecular weight (MW) and molar ratio of D-mannuronate to L-guluronate (M/G ratio) are dependent on the algal species and harvest time as well as the location of the polymer in plants [10]. The $\mathrm{M} / \mathrm{G}$ ratio and MW of alginate affect on properties of alginates [6,17].

The relative molar ratio of mannuronate to guluronate in the alginate hydrolyzed with $2 \mathrm{~N}$ sulfuric acid increased with reaction time [10]. Two partitions of polymannuronate with a purity of $80.9 \%$ and polyguluronate with a purity of $62.8 \%$ were isolated from the alginate hydrolyzed with $8.0 \%$ sulfuric acid for $3 \mathrm{hr}$ and sequentially with $2 \mathrm{~N}$ sulfuric acid for $2 \mathrm{hr}$ [2]. The MW and viscosity of alginate decreased according to the increased reaction temperature, time and concentration of hydrochloric acid, whereas solubility and emulsifying ability increased [14]. Polymannuronate with a

\footnotetext{
*Corresponding author

Tel : +82-51-200-7593, Fax : +82-51-200-7505

E-mail : jwlee@mail.donga.ac.kr
}

purity of $92 \%$ and polyguluronate with a purity of $87 \%$ were isolated from alginate hydrolyzed with hydrochloric acid for $2 \mathrm{hr}$ at $100^{\circ} \mathrm{C}$ [10]. The Nucleosil $10 \mathrm{SB}$ and Zorbax column chromatography were used to separate uronic acid from alginate hydrolyzed with acetic acid [23]. Isolation of polymannuronate and polyguluronate from alginates hydrolyzed with sulfuric acid was conducted by the column chromatography with the specific concentration, velocity and $\mathrm{pH}$ of potassium phosphate solution as an elution buffer [9].

Major study on preparation of alginate with low MW and isolation of polymannuronate and polyguluronate for new applications of seaweed alginate has been investigated with inorganic acid such as hydrochloric and sulfuric acids. However, the recent method for isolation of polymannuronate and polyguluronate with inorganic acids resulted in environmental contaminations. An enzymatic method for preparation of homopolymannuronate blocks and strictly alternating sequences of mannuronic and guluronic units has been reported [1,12], but it is a costly process to apply for commercial production of polymannuronate. The new and simple method with organic acids, which have been used as food additives for its safety, for preparation of hydrolyzed alginate with low MW and isolation of polymannuronate and polyguluronate was developed in this 
study. Isolated polymannuronate as a functional additives and/or foods will be used for new applications of seaweed alginate.

\section{Materials and Methods}

\section{Hydrolysis of seaweed alginate by organic acids}

Seaweed alginate was kindly donated from the Myengsin Co. Ltd. (Kyungsangnam-Do, Korea). It was prepared from Macrocystis pyrifera and used for this study. Alginates with a MW of 1,283 $\mathrm{kDa}$ was mixed with preheated acetic acid, citric acid, lactic acid, malic acid, oxalic acid., succinic acid, and tartaric acid. Alginate (30 g) was mixed with $600 \mathrm{ml}$ of $0.4 \mathrm{M}$ organic acid and incubated at $100^{\circ} \mathrm{C}$ for $3 \mathrm{hr}$. After that, reaction mixture was neutralized with $1 \mathrm{M} \mathrm{NaHCO}_{3}$ and mixed with same volume of $95 \%$ ethanol for precipitation.

Isolation of polymannuronate and polyguluronate from hydrolyzed alginates

Alginate was dissolved in preheated $0.4 \mathrm{M}$ acetic acid. The reaction for hydrolysis of alginate maintained for $5 \mathrm{hr}$ at $100^{\circ} \mathrm{C}$. The resulting mixture was centrifuged at $5,000 \times$ $g$ for $20 \mathrm{~min}$ after adjustment of $\mathrm{pH}$ to $2.9 \pm 0.1$. Polymannuronate in supernatant and polyguluronate in precipitate were separated and neutralized with $1 \mathrm{M} \mathrm{NaHCO}$. Each part was mixed with same volume of $95 \%$ ethanol for precipitation. Each precipitate was dissolved in distilled water and the above procedure was repeated 2 or 3 times.

\section{Analytic methods}

The molar composition of mannuronate and guluronate in alginates hydrolyzed with organic acids was measured with high pressure liquid chromatography (HPLC) using a Spectra Physics P2000 system controller equipped with
Whatman partisil 10-SAX anion exchange column $(250 \times 4.6$ $\mathrm{mm}$ i.d.) [9]. The D-mannuronic acid lactone and L-gulucuronic acid lactone used for standard materials were purchased from Sigma-Aldrich (St. Louis, MO). The buffer, 0.02 $\mathrm{M} \mathrm{KH}_{2} \mathrm{PO}_{4}$ ( $\mathrm{pH}$ 4.6) solution containing 5\% methanol, was used for elution.

The MWs of the alginates hydrolyzed with organic acids were measured by the gel chromatography equipped with

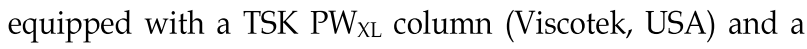
RI detector. Pullulan standards (Showa Denko, Japan) with narrow polydispersity and MWs ranging from $5.80 \times 10^{3}$ to $1.60 \times 10^{6}$ were used to plot a calibration curve [8]. Deionized water was used as a mobile phase at a flow rate of 1.0 $\mathrm{ml} / \mathrm{min}$. The sample concentration and injection volume were $5.0 \mathrm{mg} / \mathrm{ml}$ and $100 \mu \mathrm{l}$, respectively. All of the sample solutions were filtered through $0.45 \mu \mathrm{m}$-pore-size filters (Adbentec MFS, Inc., Japan) before injection.

Measurement of total sugars in fractionated samples was carried out by the phenol sulfuric acid method [7]. The glucose (Sigma-Aldrich, USA) was used for the calibration curve of total sugar as standard.

\section{Results}

\section{Effect of organic acids on hydrolysis of alginate}

Organic acids including acetic acid, citric acid, lactic acid, malic acid, oxalic acid, succinic acid and tartaric acid were used for hydrolysis of alginate (Table 1). The reaction temperature and time for hydrolysis of alginate with $0.4 \mathrm{M}$ organic acids were $100^{\circ} \mathrm{C}$ and $3 \mathrm{hr}$. Molar percentages of alginates hydrolyzed with organic acids ranged from 76.3 to $83.2 \%$. Molar ratios of mannuronate to guluronate in hydrolyzed alginate ranged from 2.62 to 2.89 . The molecular weight of alginate hydrolyzed with organic acid ranged from 7.5 to $53.2 \mathrm{kDa}$. The molecular weight of alginate hy-

Table 1. Effect of organic acids on hydrolysis of alginate ${ }^{a}$

\begin{tabular}{|c|c|c|c|c|c|}
\hline \multirow{2}{*}{ Organic acid } & \multicolumn{3}{|c|}{ Composition of hydrolyzed alginate } & \multirow{2}{*}{$\begin{array}{l}\text { Molecular weight } \\
\qquad(\mathrm{kDa})\end{array}$} & \multirow{2}{*}{$\begin{array}{l}\text { Molar percentage } \\
\text { of hydrolysis }(\%)\end{array}$} \\
\hline & Mannuronate (\%) & Guluronate (\%) & $\mathrm{M} / \mathrm{G}$ ratio & & \\
\hline Acetic acid & 72.61 & 27.39 & 2.65 & 7.5 & 78.7 \\
\hline Citric acid & 73.73 & 26.27 & 2.81 & 24.0 & 78.3 \\
\hline Lactic acid & 70.13 & 29.87 & 2.35 & 33.8 & 76.3 \\
\hline Malic acid & 69.87 & 30.13 & 2.32 & 53.2 & 78.4 \\
\hline Oxalic acid & 74.69 & 25.31 & 2.95 & 37.6 & 83.2 \\
\hline Succinic acid & 68.69 & 31.31 & 2.19 & 35.4 & 78.6 \\
\hline Tartaric acid & 71.84 & 28.16 & 2.55 & 33.1 & 79.2 \\
\hline
\end{tabular}

${ }^{\mathrm{a}}$ Reaction temperature and time with $0.4 \mathrm{M}$ of organic acids were $100^{\circ} \mathrm{C}$ and $3 \mathrm{hr}$. 
Table 2. Effect of acetic acid concentration on hydrolysis of alginate ${ }^{\text {a) }}$.

\begin{tabular}{|c|c|c|c|c|c|}
\hline \multirow{2}{*}{$\begin{array}{l}\text { Concentration } \\
\qquad(\mathrm{M})\end{array}$} & \multicolumn{3}{|c|}{ Composition of hydrolyzed alginate } & \multirow{2}{*}{$\begin{array}{l}\text { Molecular weight } \\
\qquad(\mathrm{kDa})\end{array}$} & \multirow{2}{*}{$\begin{array}{l}\text { Molar percentage } \\
\text { of hydrolysis }(\%)\end{array}$} \\
\hline & Mannuronate $(\%)$ & Guluronate(\%) & $\mathrm{M} / \mathrm{G}$ ratio & & \\
\hline 0 & 73.2 & 26.8 & 2.73 & $1,283.0$ & 0.0 \\
\hline 0.2 & 73.6 & 26.3 & 2.80 & 204.0 & 81.4 \\
\hline 0.4 & 74.8 & 26.2 & 2.85 & 102.3 & 80.6 \\
\hline 0.6 & 73.2 & 26.7 & 2.74 & 62.1 & 80.3 \\
\hline 0.8 & 72.8 & 27.2 & 2.68 & 32.5 & 79.8 \\
\hline 1.0 & 72.3 & 2.4 & 2.64 & 17.3 & 79.4 \\
\hline
\end{tabular}

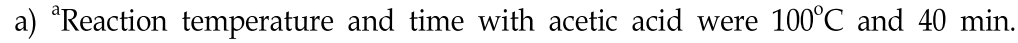

drolyzed with acetic acid was $7.5 \mathrm{kDa}$ whereas that with malic acid was $53.2 \mathrm{kDa}$. The molar ratio of mannuronate to guluronate $(\mathrm{M} / \mathrm{G})$ in partially hydrolyzed alginate with organic acids ranged from 2.19 to 2.95 . There was no significant difference in the molar ratio of $M / G$ in hydrolyzed alginates. The molar ratio of $M / G$ in the intact alginate used in this study was 2.68 .

Effect of acetic acid concentration on hydrolysis of alginate

Alginate was hydrolyzed with various concentrations of acetic acid, known as the most effective hydrolytic agent in this study, at $100^{\circ} \mathrm{C}$ for $40 \mathrm{~min}$ (Table 2). The molar percentage and $\mathrm{Mw}$ of hydrolyzed alginates ranged from 79.4 to $81.4 \%$ and from 17.3 to $204.0 \mathrm{kDa}$, respectively. Generally speaking, the higher the concentration of acetic acid was used to hydrolyze alginate, the lower the MW of hydrolyzed alginate was obtained as shown in Fig. 1. The equation from the correlation between the MW of hydrolyzed alginate and the concentration of acetic acid was $Y=776,400-986,700 X$. The $\mathrm{Y}$ and $\mathrm{X}$ mean the MW of hydrolyzed alginate and the concentration of acetic acid, respectively.

\section{Effect of reaction time on hydrolysis of alginate}

Alginate was hydrolyzed with $0.4 \mathrm{M}$ acetic acid at $100^{\circ} \mathrm{C}$ for various times (Table 3). Molar percentage and MW of hydrolyzed alginates ranged from 78.6 to $80.7 \%$ and from 4.3 to $432.0 \mathrm{kDa}$, respectively. The molecular weight of alginate lineally decreased with reaction time whereas the molar ratio of $M / G$ in hydrolyzed alginates seemed to be constant. There was no big difference in the molar percentage of hydrolyzed alginates with different reaction times but the correlation between the MW of alginate hydrolyzed with acetic acid and the reaction time was observed as shown in Fig. 2. The equation was $Y=506,509-2,901 X$ where $Y$ and $X$ mean the MW of hydrolyzed alginate and the reaction time with
Fig. 1. Correlationship between the molecular weight of partially hydrolyzed alginate at $100^{\circ} \mathrm{C}$ for $40 \mathrm{~min}$ and concentration of acetic acid.

$0.4 \mathrm{M}$ acetic acid, respectively. Initial reaction for hydrolysis of alginate up to $60 \mathrm{~min}$ was more vigorous than late one.

Isolation of polymannuronate and polyguluronate from hydrolyzed alginates

The process for isolation of polymannuronate and polyguluronate from the alginate hydrolyzed with $0.4 \mathrm{M}$ acetic acid at $100^{\circ} \mathrm{C}$ was developed in this study with modification of Gaceas' procedure as shown in Fig. 3 [9]. Polymannuronate fractions were dissolved in acidic condition such as in $\mathrm{pH} 2.9$ whereas polyguluronate fractions were precipitated under the same acidic condition. The molar percentage of mannuronate in the polymannuronate isolated from the alginate hydrolyzed with the process developed in this study increased with reaction time for hydrolysis of alginate. On the basis of the high performance liquid chromatographic analysis of D-mannuronate lactone and L-guluronate lactone as shown in Fig. 4, molar percentages of mannuronates in polymannuronates isolated from 
Table 3. Effect of reaction time with acetic acid on hydrolysis of alginate ${ }^{\text {a) }}$

\begin{tabular}{|c|c|c|c|c|c|}
\hline \multirow{2}{*}{$\begin{array}{l}\text { Reaction time } \\
\text { (min) }\end{array}$} & \multicolumn{3}{|c|}{ Composition of hydrolyzed alginate } & \multirow{2}{*}{$\begin{array}{l}\text { Molecular weight } \\
\qquad(\mathrm{kDa})\end{array}$} & \multirow{2}{*}{$\begin{array}{l}\text { Molar percentage } \\
\text { of hydrolysis }(\%)\end{array}$} \\
\hline & Mannuronate $(\%)$ & Guluronate(\%) & $\mathrm{M} / \mathrm{G}$ ratio & & \\
\hline 0 & 73.2 & 26.8 & 2.73 & $1,283.0$ & 0.0 \\
\hline 10 & 73.4 & 26.6 & 2.76 & 432.0 & 80.7 \\
\hline 20 & 74.2 & 26.2 & 2.83 & 245.6 & 80.8 \\
\hline 40 & 74.3 & 25.7 & 2.89 & 105.2 & 80.4 \\
\hline 60 & 74.0 & 26.0 & 2.85 & 42.7 & 80.3 \\
\hline 120 & 73.6 & 26.9 & 2.74 & 9.2 & 79.3 \\
\hline 180 & 72.6 & 27.4 & 2.65 & 7.5 & 78.7 \\
\hline 240 & 72.4 & 27.6 & 2.62 & 4.3 & 78.6 \\
\hline
\end{tabular}

a) Reaction temperature and concentration of acetic acid were at $100^{\circ} \mathrm{C}$ and $0.4 \mathrm{M}$.

Fig. 2. Correlationship between the molecular weight of partially hydrolyzed alginate at $100^{\circ} \mathrm{C}$ and reaction time with acetic acid.

alginate hydrolyzed with $0.4 \mathrm{M}$ acetic acid at $100^{\circ} \mathrm{C}$ were $75 \%$ for $1 \mathrm{hr}, 90 \%$ for $3 \mathrm{hr}$, and $98 \%$ for $5 \mathrm{hr}$ of reaction time as shown in Fig. 5.

\section{Discussion}

The molecular weight of alginate hydrolyzed with acetic acid in this study lineally decreased with increasing concentration of acetic acid and reaction time. The hydrolytic kinetics of alginate with acetic acid showed the 1st order reaction. This result was coincided with the report where the $\mathrm{Mw}$ of alginate lineally decreased with increased reaction time and concentration of hydrochloric acid [14]. Hydrolysis of seaweed alginates with various concentrations of sulfuric acid for different reaction time had been reported [13] and rapid hydrolysis of alginate isolated from Laminaria digitata with $1 \mathrm{M}$ oxalic acid at $100^{\circ} \mathrm{C}$ for $1 \mathrm{hr}$ had been

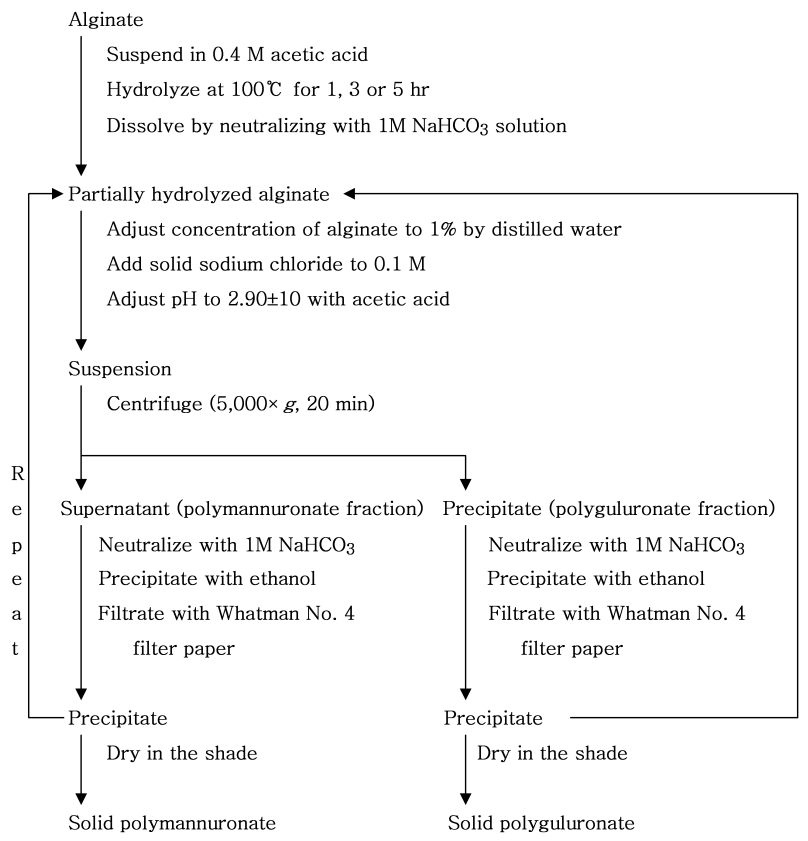

Fig. 3. Process for isolation of polymannuronate and polyguluronate from partially hydrolyzed alginates with 0.4 $\mathrm{M}$ acetic acid.

observed [11]. Partial hydrolysis due to oxidation of alginates with organic acids as well as inorganic acids resulted in decreasing of their MW such as other polysaccharides.

Alginate is one of the few polysaccharide that can be obtained from both eukaryotes and prokaryotes. Unlike bacterial alginates, seaweed alginates consist of $[1 \rightarrow 4]$ linked block copolymers of $\beta$-D-mannuronate (polymannuronate) and $\alpha$-L-guluronate (polyguluronate) $[5,20]$. In the mechanism of gel formation, which is dimerization of polyguluronate sequences with divalent cations chelated between the alginates chains, the size of divalent cation is one of most important factors. The size of calcium ion other than those of divalent cations allows it to fit into the space formed 
Fig. 4. High performance liquid chromatograms of (a) D-mannuronate lactone $(\mathrm{M})$, (b) L-guluronate lactone $(\mathrm{G})$ and (c) mixture of D-mannuronate lactone and L-guluronate lactone $(1: 1)$ eluted with $20 \mathrm{mM} \mathrm{KH} \mathrm{PO}_{4}(\mathrm{pH} 4.6)$ containing $5 \%$ methanol at a flow rate of $1.0 \mathrm{ml} / \mathrm{min}$.

Fig. 5. High performance liquid chromatograms of polymannuronate isolated from alginates hydrolyzed with $0.4 \mathrm{M}$ acetic acid for (a) $1 \mathrm{hr}$ (b), $3 \mathrm{hr}$ and (3) $5 \mathrm{hr}$ eluted with $20 \mathrm{mM} \mathrm{KH} \mathrm{PO}_{4}(\mathrm{pH} 4.6)$ containing $5 \%$ methanol at a flow rate of $1.0 \mathrm{ml} / \mathrm{min}$.

by guluronate residues between intra and inter molecules of seaweed alginates $[18,19]$. Among organic acids used in this work, acetic acid which showed strong hydrolyzing effect may be due to characteristics of acetic acid with rela- tively smaller molecular size and conformational feature of seaweed alginate.

Partial hydrolysis of alginate with acetic acid may occur first at the linkage of alternative residences due to its conformational feature of alginate. Polymannuronate adopts flat ribbon-like 2-fold chain confirmations in the solid state, similar to those found in $\beta-1,4$ diequatorially linked polymers such as cellulose [3,21], while polyguluronate adopts a buckled 2-fold chain confirmation [4]. Partial hydrolysis of alginate with acetic acid resulted in the mixture of polymannuronate and polyguluronate. The solubility of alginate at low $\mathrm{pH}$ depends on the uronic acid composition of the samples [11]. Difference in solubility due to its composition of uronic acids in polymannuronate and polyguluronate might be possible to separate each fraction.

Some of polysaccharides including alginate affects on cholesterol metabolism in rat [16]. The alginate with higher content of D-mannuronic acid reduced cholesterol levels in liver and blood and increased polyenoic acid in serum lipid of rats [22]. Partially hydrolyzed alginate with hydrochloric acid also reduced cholesterol levels in liver and blood of cholesterol-fed rats [15]. In this work, a new and simple method for isolation of polymannuronate with low MW from alginate hydrolyzed with acetic acid was developed. The more detailed functional study of polymannuronate with low MW will be followed to apply it for the anti-cholesterol agent in the food industry as a food additive.

\section{Acknowledgement}

This study was supported by research funds from Dong-A University.

\section{References}

1. An, Q., G. Zhang, H. Wu, Z. Zhang, W. gong, Y. Liu, X. $\mathrm{Li}$ and Y. Murata. 2008. Production and partial properties of alginase from newly isolated Flavobacterium sp. LXA. Process Biochem 43, 842-847.

2. Annison, G., N. W. H. Cheetham and I. Couperwhite. 1983. Determination of the uronic acid composition of alginates by high-performance liquid chromatography. J. Chromat. 264, 137-143.

3. Atkins, E. D. and I. A. Nieduszynski. 1973. Structural components of alginic acid. I. the crystalline structure of poly- $\beta$ D-mannuronic acid. results of $x$-ray diffraction and polarized infrared studies. Biopolym 12, 1865-1878.

4. Atkins, E. D. and I. A. Nieduszynski. 1973. Structural components of alginic acid. II. the crystalline structure of poly- $\beta$ - 
L-guluronic acid. results of x-ray diffraction and polarized infrared studies. Biopolym 12, 1879-1887.

5. Donati, I., A. Gamini, G. Skjåk-Bræk, A. Vetere, C. Campa, A. Coslpvi and S. Paoletti. 2003. Determination of the dyadic composition of alginate by means of circular dichroism: a fast and accurate improved method. Carbohydr. Res. 338, 1139-1142.

6. Draget, K. I., G. Skjåk-Bræk and O. Smidsrød. 1994. Alginic acid gels: the effects of alginate chemical composition and molecular weight. Carbohydr. Polym 25, 31-38.

7. Dubois, M., K. A. Gillus, J. K. Hamilton, P. A. Rebers and F. Smith. 1956. Colorimetric method for sugars and related substances. Anal. Chem 28, 350-356.

8. Fujihara, M. and T. Nagumo. 1989. Determination of the molecular weights of alginates by agarose gel filtration. $J$. Chromat. 465, 386-389.

9. Gacesa, P., A. Squire and P. J. Winterburn. 1983. The determination of the uronic acid composition of alginates by anion-exchange liquid chromatography. Carbohydr. Res. 118, 1-8.

10. Haug, A. and B. Larsen. 1962. Quantitative determination of the uronic acid composition of alginates. Acta Chem Scand 16, 1908-1918.

11. Haug, A., B. Larsen and O. Smidsrod. 1966. A study of the constitution of alginic acid by partial acid hydrolysis. Acta Chem Scand 20, 183-190.

12. Heyraud, A., P. Colin-Morel, C. Gey, F. Chavagnat, M. Guinand and J. Wallach. 1998. An enzymatic method for preparation of homopolymannuronate blocks and strictly alternating sequences of mannuronic acid and guluronic units. Carbohydr. Res. 308, 417-422.

13. Hirst, E. L., E. Perrcival and J. K. Wold. 1964. The structure of alginic acid. part IV. partial hydrolysis of the reduced polysaccharide. J. Chem Soc. 8, 1493-1499.
14. Lee, D. S., H. R. Kim and J. H. Pyeun. 1998. Effect of low-molecularization on rheological properties of alginate. J. Kor. Fish Soc. 31, 82-89.

15. Lee, D. S., T. J. Nam and J. H. Pyeun. 1998. Effect of low molecular alginates on cholesterol levels and fatty acid compositions of serum and liver lipids in cholesterol-fed rats. J. Kor. Fish Soc. 31, 399-408.

16. Lee, Y. A. and M. H. Kim. 2008. The effect of sea tangle extract on serum lipid level in ovariectomized rats. J. Life Sci. 18, 249-254.

17. Mizuno, H., H. Sato, N. Iso, N. Onda, K. Noda and K. Takada. 1983. Mannuronic to guluronic acid ratios of alginic acids prepared from various brown seaweeds. Bull. Jap. Soc. Fish 49, 1591-1593.

18. Morris, E. R., D. A. Rees and D. Thorn. 1978. Chiroptical and stoichiomtric evidence of specific primary dimerization process in alginate gelation. Carbohydr. Res. 66, 145-154.

19. Morris, E. R. and D. A. Rees. 1980. Competitive inhibition of interchain interactions in polysaccharide systems. J. Mol. Biol. 138, 363-374.

20. Penman, A. and G. R. Sanderson. 1972. A method for the determination of uronic acid sequence in alginates. Carbohydr. Res. 25, 273-282.

21. Rees, D. A. 1972. Shapely polysaccharides. Biochem J. 126, 257-273.

22. Suzuki, T., K. Nakai, Y. Yoshie, T. Shirai and T. Hirano. 1993. Effect of sodium alginates rich in guluronic acid and mannuronic acids on cholesterol level and digestive organs of high-cholesterol-fed rats. Nippon Suisan Gakkaishi 59, 545-551.

23. Voragen, A. G. J., H. A. Schols, J. A. De Vries and W. Pilnik. 1982. High-performance liquid chromatographic analysis of uronic acids and oligogalacturonic acids. J. Chromat. 244, 327-336.

\section{초록 : 유기산에 의해 가수분해된 알긴산에서 폴리만뉴론산과 폴리글루론산을 분리하는 간단한 방법}

이동수 · 신명교 ${ }^{1}$ 변재형 ${ }^{2} \cdot$ 이진우 ${ }^{*}$

(한국바이오폴리머 생물공학연구소, ${ }^{1}$ 한국생산기술원 환경에너지본부, ${ }^{2}$ 부경대학교 식품생명공학부, ${ }^{3}$ 동아대학 교 생명공학과)

분자량이 $1,283 \mathrm{kDa}$ 인 알긴산을 $0.4 \mathrm{M}$ 유기산을 사용하여 $100^{\circ} \mathrm{C}$ 에서 3 시간 반응시켜 가수분해하였다. 유기산에 의하여 가수분해된 알긴산의 분자량은 7.5 에서 $53.2 \mathrm{kDa}$ 이었다. 유기산으로 가수분해된 알긴산을 구성하는 만뉴론 산과 글루론산의 비율은 가수분해하지 않은 알긴산과 비교하여 큰 차이가 없었다. 사용한 유기산 중에서 알긴산을 가수분해하는 가장 효과적인 유기산은 초산이었다. 사용한 초산의 농도 및 반응시간이 증가할수록 가수분해된 알긴산의 분자량은 감소하였다. 본 연구를 통하여 가수분해된 알긴산의 분자량과 초산의 농도 및 반응시간과의 상관관계를 나타내는 관계식을 구하였다. 초산으로 가수분해한 알긴산의 $\mathrm{pH}$ 를 조절하여 폴리만뉴론산과 폴리글루 론산을 분리하였다. 초산과 반응하는 시간이 증가할수록 폴리만뉴론산에 존재하는 만뉴론산의 비율은 증가하였다. 폴리만뉴론산에 존재하는 만뉴론산의 비율은 $100^{\circ} \mathrm{C}$ 에서 $0.4 \mathrm{M}$ 초산과 1 시간, 3 시간 및 5 시간 반응하였을 경우에 각각 $75 \%, 90 \%$ 및 $98 \%$ 이었다. 